panying photograph was snapped at the moment when slipping began. The occurrence emphasised the conclusion that such peaks are forms of accumulation, not erosion.

From the foregoing observations $I$ infer that if a country be silted with loose, dry sand under the action of strong wind constant in direction until the dunes attain maximum height, the sky-line will be serrated by peaks not only when viewed at right angles to the wind but also when looking up- or down-wind ; that these peaks are not remnants of erosion, but accumulations ; and that the normal crest-line of maximum dunes in a sand sea subject to strong wind of constant direction is not level, but peaked.

Dr. Sven Hedin records in his "Scientific Results" that in the eastern part of the desert of Lop, the windward part of the Tarim basin, small dunes are formed during the dying-down of a storm, but when the wind gathers force in the next storm are dispersed. Mr. A. E. Douglass ${ }^{3}$ and Prof. S. I. Bailey ${ }^{4}$ record that in the windward part of the Peruvian desert of Islay the sand, which is derived from an extraneous source, collects in isolated dunes less than four feet high which are not permanent, being dispersed after a time, blown to pieces by the wind. As soon as a height of four feet is attained, permanence is assured, but does

${ }^{3}$ Appalachia, vol. 12, No. 1.

Annals of the Astronomical Observatory of Harvard College, 29, Part II.

\title{
High Frequency Sound Waves of Small Intensity and their Biological Effects.
}

By Prof. E. Newton Harvey, Princeton University, and Alfred L. Loomis, the Loomis Laboratory, Tuxedo Park, New York.

R. W. WOOD and one of us (Loomis) have described (Phil. Mag., 4, 417; September 1927) certain physical and biological effects observed with high frequency sound waves of great intensity. To obtain this great intensity, high potentials (of the order of 50,000 volts) are required, and the oscillating piezo-electric quartz crystal must be operated in an oil bath. This method is not suitable for observing biological material under a microscope.

For this purpose we have constructed a special device which can be attached directly to a microscope and operated by an oscillator of relatively low power but must be accurately tuned to resonance with the quartz crystal. The entire oscillator (Fig. 1) is very compact and weighs only eighteen pounds. It takes current directly from the 110 volt A.C. lighting circuit and employs a 75 watt tube (Radiotron 852) with two small transformers (one giving 8 volts for the filament, the other 1100 volts for the plate). The microscope with quartz crystal is set up about three feet from the oscillator and connected through a shielded lead, so that movements of the operator will not materially vary the capacity and thus the frequency. Two controls which connect with the oscillator are operated from the microscope, one varying the plate and filament current and the other the frequency.

The crystal mounting consists of a bakelite ring not occur nearer than twenty miles from the wind. ward edge of the desert. From this position the moving mounds grow during a very short course of travel from four feet to fifteen feet in height, which is the characteristic maximum throughout the remaining twenty-five miles of desert plateau. The dimensions and movement of a dune near La Joya railway station have been recorded for several years. The rate of progress was remarkably uniform, 62, 57, 63, 63, 63 feet in successive years, and the height and breadth of the crescentic mound was almost constant. The length and direction of the tapering cusps or horns varied, but the quantity of sand added to or subtracted from the cusps was very small in proportion to the total mass of the dune, not, I think, greater than the quantity contained in one of the rudimentary dunes which form and disperse in the windward part of the desert according to the vicissitudes of weather.

It is well to bear in mind that most of the recorded observations of the movement of sand. grains in deserts have been made during moderate breezes, when the effect of a mound of sand is to provide shelter to leeward. During storms the atmosphere in a sand sea is usually so blinding and suffocating that no precise observations are made, but in this weather the increased force of wind at the summit of the dune is sufficient to cause dis. persal, a reversal of the mode of action which we commonly observe. which is placed directly on the microscope stage. Fastened to the top of this ring is a thin foil electrode connected to the high tension lead. The quartz crystal is placed on top of this electrode. The crystal is $54 \mathrm{~mm}$. in diameter and $7.02 \mathrm{~mm}$. thick. It is cut with its electric axis perpendicular to the plane of the disc. Its natural frequency is 406 kilocycles per second. The specimen to be examined is placed on the centre of the upper surface of this disc and protected with a cover glass. On top is placed the upper electrode, which is earthed. The frame of the microscope is also earthed. A small hole through the centre of the lower electrode permits adequate illumination of the specimen, and a similar hole through the upper electrode permits the light from the specimen to enter the microscope objective.

Observing under a high-power microscope, it has been possible to follow the progressive destruction of frog blood corpuscles. The oval cells at first become warped and twisted. Strained areas appear and the colour fades, leaving a pale distorted shadow. Human blood corpuscles are likewise twisted and sometimes broken up into many small globules like an emulsion of oil. Individual bacteria can be studied, but while they can be violently agitated, we have not yet been able to observe their destruction under the microscope.

If a fine emulsion of oil is examined, an individual

No. 3051, VoL. 121] 
droplet of oil can be singled out and made to rotate rapidly in either direction at speeds that can be accurately controlled by varying slightly the frequency of the oscillating circuit.

An excellent material to illustrate the effects of these waves is a leaf of Elodea, two cell layers in thickness. The protoplasm with suspended chloroplasts forms a thin layer about the cellulose cell wall enclosing the vacuole of cell sap. High frequency sound waves of low intensity passed through these cells cause the protoplasm to rotate very much as in the normal rotation or cyclosis of Elodea. Increasing the supersonic intensity increases the movement until the whole cell is a rapidly whirling mass of protoplasm, fragments of which are torn loose and rotate as small balls in the vacuole. The effect is very striking and might almost lead one to conclude that the normal cyclosis of this plant was caused by high frequency vibrations. The normal protoplasmic rotation of Elodea is stopped by the waves unless they are of very low intensity. Rotation begins again provided the irradiation has not been too strong. Sugar - plasmolysed Elodea cells are affected in the same manner as are the unplasmolysed ones, the whole protoplasm rotating rapidly, until, with increasing intensity, the mass finally bursts and scatters the chloroplasts, still whirling, throughout the cell. Nitella cells when exposed to radiation have the chloroplasts torn from the walls of the cell and whirled rapidly, leaving a clear area which had originally been a uniform green colour.

This stirring of the cell contents is one of the most characteristic effects of supersonics. The smaller the cell, the more difficult it is to stir, but we have observed the rapid rotation of the chloroplasts in moss cells the diameter of which averages $12 \mu$. The phenomenon is not connected with living cells only, but may be observed in Elodea killed by heating or by chloroform, although a greater intensity is necessary since the protoplasm is coagulated on death, and the coagulated mass is only churned with some difficulty.

This microscopic method offers a promising means of attack upon the problem of influencing the development of eggs of various species, as forces can thus be applied inside an egg at different stages of its development without the necessity of puncturing the cell wall or enveloping membrane. The results immediately suggest the interesting possibility of converting an egg with determinate cleavage into an indeterminate one by thoroughly mixing and redistributing the organ-forming substances of its interior. We are now engaged upon this and allied problems, the results of which we expect to publish in due course.

No effects of the waves have been noted that could be clearly traced to an influence on chemical processes in cells, although it is known that high intensity waves influence certain chemical systems, especially metastable ones (W. T. Richards and A. L. Loomis, Jour. Am. Chem. Soc., 49, 3086; 1927). The phenomena in living organisms, apart from temperature rise, are connected with mechanical effects, the most striking of which might be best described as ' intracellular stirring.'

In certain biological studies where great intensity is desired, and it is not necessary to observe under the microscope, a high-powered oscillator is required.

Using such an oscillator and placing the material to be treated in test tubes which were subjected to the vibrations, Wood and Loomis caused the rupture of filaments of Spirogyra, the tearing of Paramocium and the laking of red blood corpuscles. This latter effect is very striking, defibrinated mammalian blood corpuscles in physiological salt solution laking completely in one minute before the average temperature of the fluid had risen to $37^{\circ} \mathrm{C}$. They also noted the killing of small fish and frogs,

$$
\text { No. 3051, VoL. 121] }
$$

but the cause of death was not determined. Using the same high-powered oscillator, we have taken small organisms like Euglena or Paramœcium and enclosed them in capillary tubes sealed at the ends. When one end of such a tube is subjected to intense vibrations the organisms are thrown in piles regularly spaced (about $2 \mathrm{~mm}$. apart, depending on the diameter of the capillary) along the tube, from which they are unable to swim. These piles represent nodes of transverse vibrations set up in the capillary. It is not that the organisms swim into these nodes but they are passively carried into the nodes, and fortunately so, for between the nodes they would be subjected to mechanical tearing that would disintegrate them. Thus, red blood corpuscles in a capillary tube are thrown into the nodes and quite unharmed by ten minutes' exposure to radiation, whereas the same corpuscles in a test tube, where convection currents carry them about, are laked in one minute. Even luminous bacteria and particles of gamboge form striæ in capillary tubes, but colloidal particles (as of benzo-purpurin, arsenic sesquisulphide, or ferric hydroxide) do not.

An emulsion of luminous bacteria in sea water in a test tube, exposed to radiation until the 
temperature rose from $1 \cdot 5^{\circ}$ to $21 \cdot 5^{\circ}$, luminesces considerably less brightly than a control tube heated from $1 \cdot 5^{\circ}$ to $21 \cdot 5^{\circ}$. The turbidity is also less in the irradiated tube, indicating that some of the bacteria have undergone cytolysis. Control experiments showed that the dimming was not due to the electric field. The luminescence of a mixture of Cypridina luciferin and luciferase was unaffected by irradiation in any way that could not be accounted for by rise in temperature.

One might expect that high frequency mechanical vibrations, carrying as much energy as they do, would be capable of stimulating muscle or nerve tissue. All attempts to demonstrate a stimulating action have failed. The sciatic nerve of a frog connected with the gastrocnemius muscle may be touched (either nerve or muscle) to a test tube violently oscillating or be immersed in a salt solution in such a test tube without stimulation and without injury. Both nerve and muscle are later found to be quite irritable to electrical stimuli. The high tension field is unable to stimulate because of its high frequency. A bull frog's heart mounted in Ringer's solution in a test tube touching the oil and connected with a heart lever for recording movement, shows no peculiarities of the contraction, but an irregularity and usually a slowing of the rate, despite the rise in temperature that accompanies the irradiation. Further observations will be necessary to analyse these peculiarities.

\section{Obituary.}

\section{Mr. W. B. Croft'.}

W ILLIAM BLEADEN CROFT died at Winchester on Mar. 23 at the age of seventy-six years. Born in 1851, the sixth son of a surgeon, Mr. C. I. Croft, he went to Christ's Hospital, and thence as a scholar to Pembroke College, Oxford, and obtained first classes in the schools of mathematics and natural science, besides rowing bow in the Pembroke boat at the head of the river.

Croft was a very remarkable man. He was appointed mathematical and then science master at Winchester College in 1874, but for the last twenty years of his service he taught only physics. He retired in 1915. During all this time he never missed an hour's teaching through ill-health. $\mathrm{He}$ was a fellow of the Physical Society, at the meetings of which he was a regular attendant, and was elected to the council in 1903 . He served several times on the committee of Section A of the British Association, and examined for the final honours school in natural science at Oxford.

Croft took little interest in chemistry, but he was a born physicist. Had he been trained in one of the great university schools of to-day, he would have achieved a fame far beyond that which fell to his lot. He had the gift of a vivid scientific curiosity, an uncanny power of pitching upon the first hint of a new discovery before others were fully awake to its importance, and a talent for experiment that almost amounted to genius. $\mathrm{He}$ was a constant reader of NATURE and other scientific periodicals, and he carefully cut out articles and pasted them into scrap-books, which he filled with comments and annotations. If anything struck him as likely to lead further, he at once got into touch with the writer of the article or letter, and repeated for himself any experiments that could be compassed in his laboratory, developing them in promising directions. Thus, for example, it came about that he was the first man in England to make a Branly coherer and to perform further experiments with Hertzian waves.

Croft was always at work on phenomena of common occurrence, and never rested until he, and some special pupils, understood its physical significance. Did a question arise about bells or fiddles? Croft set to work immediately upon the fundamentals and harmonics of college bells, and called in the assistance of the musical staff. His photographs of diffraction phenomena were extraordinarily good, and still enrich the pages of Edser's "Light for Students." Light and sound were perhaps his chief interests, but he did good work in electricity also.

A teacher for the few rather than the many, to those of his pupils who by diligence and aptitude proved themselves worthy of the meticulous care which he bestowed upon his lectures, Croft imparted all that they could receive of his knowledge of and reverence for science, and his gift of seeing the essential and planning an experimental approach; and he kept touch with them in after years. A permanent memorial of him is left in the collection of interesting apparatus which he gathered in the College laboratory; but above all, he will be remembered by his pupils, his colleagues, and his many friends for infinite courtesy and thoughtfulness. He leaves a widow, three sons, and a daughter.

\section{WE regret to announce the following deaths :}

Prof. Wilhelm von Branca, emeritus professor of geology and palæontology in the University of Berlin, distinguished for his work on the evolutionary history of man and other animals and for work on the development of flight, on Mar. 12, aged eighty-three years.

Prof. Elmer E. F. Creighton, of the General Electric Co., Schenectady, a well-known consulting electrical engineer, on Jan. 13, at the age of forty-nine years.

Mr. Alexander E. Outerbridge, of the William Sellers Company, professor of metallurgy at the Franklin Institute, known for his work on the molecular physics of iron, on Jan. 13, aged seventy-seven years.

Mr. E. A. Reynolds-Ball, author of many travel and guide books, including "Mediterranean Winter Resorts," aged sixty-nine years.

M. Emile Senart, president of the Société Asiatique of Paris and an honorary fellow of the Royal Asiatic Society of Great Britain, and author of "Les Castes dans l'Inde," on Feb. 21, aged eighty years.

Mr. G. Chisholm Williams, a distinguished pioneer in the medical use of X-rays, on April 10, aged sixty-three years.

No. 3051, VoL. 121] 